\title{
Mission Possible
}

Jane Hass Philbrick, Savannah State University, USA

Reginald Leseane, Savannah State University, USA

Barbara D. Bart, Savannah State University, (retired), USA

William Dowling, Savannah State University, USA

\begin{abstract}
"Reading is to the mind what exercise is to the body." Sir Richard Steele
\end{abstract}

The authors examine the impact of a program designed to encourage students to read popular business magazines. The results suggest that a reading program can improve student knowledge of current events, but that more work is needed to encourage students to attain timely knowledge of the current environment of business.

\section{INTRODUCTION}

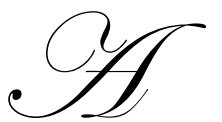

lmost without exception, when employers are queried about the qualities that they look for in their applicants, communication skills and the ability to work in groups are ranked in the top five [3]. Effective communication requires one to couch information in relative terms so that it is easily understood by the recipient. Thus, a modicum of broad based knowledge is required. Additionally, a dimension of effective group behavior invariably involves participation in "issues of the day" discussions. Further, students need an awareness of world events given the increasing globalization of business. For educators, the implication is clear. To properly prepare our students, we must incorporate within the curriculum the conveyance of a mechanism whereby students become knowledgeable generally about the world they live in and specifically about the business world. Not doing so might well cause our students to make decisions that are not in the best interests of the firm and thus would sharply diminish the probability of our students' success. As educators, the authors feel strongly enough about this issue to include it as part of the mission statement of their College of Business Administration (COBA). We are committed to provide knowledgeable graduates who can compete effectively in our community.

Last semester, one of the authors received an email from a recent graduate. A portion of that email is presented below. Interestingly, Thomas Mitchell echoed these exact sentiments by suggesting that employees can be more involved in "water cooler talk" just by catching up on current events [11].

....I never thought I'd say it, but I can't tell you how glad I am you made us read those current events articles. Everyday when we get to work, we talk about stuff going on and you can't even talk if you haven't been reading about business stuff - I admit I hadn't been keeping up but I sure am now.....

Booth [1] and Clark \& Keller [2] lament that Americans know very little about the news, that they fail miserably at quizzes involving current events. One survey found that only $24 \%$ of American respondents could name two Supreme Court justices but $77 \%$ could name at least two of Disney's seven dwarfs. Jeffrey Webb, a college professor, said "everyone who has a conscience in my line of work [higher education] is obsessing over how to change teaching methods so that students are 'at maximum risk of learning."'[1]. Clark and Keller [2] point out that even given the publicity of the Iraqi War, sixty percent of Americans between the ages of 16 and 24 cannot locate Iraq on a map of the Middle East. Further, The faculty of COBA, at their retreat, agreed to undertake to improve the current business knowledge of their students. Faculty formally adopted a proposal specifying that Business Week would be required reading in all classes and that students would be strongly encouraged to purchase the weekly magazine. Faculty believed that such reading would improve students' core knowledge of current events at a minimum. Additionally, faculty were of the opinion that personal access to a magazine related to their major in college could improve scores on the reading portion of a state mandated exam, improve communication confidence and ability, and 
provide a competitive advantage.

One of the authors of this paper, with the input from a variety of instructors in the College of Business Administration, developed a short current events business quiz (CEBQ) composed of both general business knowledge questions and very current business issue questions [see Appendix 1]. Prior to making the purchase of the subscription mandatory, the authors felt that assessing the value of this requirement should be investigated.

\section{LITERATURE REVIEW}

An article on the value of magazines as a classroom resource [10], suggests that not only can reading magazines be pleasurable but that knowledge can be gained, shared and multiplied. Garramone and Atkin [4] found that newspaper and magazine reading has a strong effect on political knowledge and participation which is consistent with the authors' College of Business Administration's mission. Reading also cultivates a sustained attention span (one that has been shown to have diminished due to graphic imagery like television and movies) [6].

Vaz [12] emphasizes the value of reading magazines in developing knowledge. The business literature on strategic human resource management highlights the importance of rewarding desirable behavior [5] [9]. Behavior that is rewarded tends to be repeated and vice-versa. The recent efforts to increase diversity in the workplace have highlighted the necessity to tie executive rewards to meeting diversity goals - just talking about it, is NOT enough [7].

\section{METHODOLOGY}

Because many classes in COBA have both a day and an evening section, there is a natural way to evaluate or assess the effect of reading Business Week. First, one class was randomly assigned as the class to require reading Business Week (by basing some exam questions on the magazine articles) and the other section (taught by the same instructor) served as the control group. The hypothesis we tested is:

Hypothesis: Students enrolled in classes in which part of their evaluation (i.e., grade) is specifically related to knowledge gained from reading Business Week will earn higher average scores on the CEBQ.

Near the end of the fall semester, 2006, nineteen students in the treatment group (i.e., those whose exams contained questions based on Business Week articles/discussion) completed the CEBQ; twenty-one students served as the control group (Business Week articles were discussed but no exam questions reflected this discussion). Both classes were upper level Operations Management sections taught by the same instructor.

The average CEBQ scores were compared using a simple $t$ test for those students in the treatment group compared with those in the control group.

There were 10 general business knowledge questions and 5 additional current business knowledge questions. Each test was scored for total number of questions answered correctly, number of general questions answered correctly, and current events questions answered correctly. The students were asked to indicate whether or not they had actually purchased a subscription to Business Week, their gender, and their class standing by number of credit hours completed.

Table 1

Sample Characteristics

\begin{tabular}{|c|c|}
\hline Males & 14 \\
\hline Females & 26 \\
\hline Bought subscription & 15 \\
\hline Did Not buy subscription & $24(1$ missing data) \\
\hline Sophomores & 1 \\
\hline Juniors & 9 \\
\hline Seniors & 30 \\
\hline
\end{tabular}


Overall, the results were abysmal. Looking at the general questions (highest possible score $=10$ ), the average score for both classes was 3.7. The average score on the current events questions (highest possible score $=5$ ), was less than 1. When broken down into the treatment versus the control groups, the average score overall on the entire test for the treatment group was significantly higher than the control group $(t=2.042, p<.03, \mu=4.6$ vs. $\mu=3.3)$.

Table 2

Summary Statistics

\begin{tabular}{|c|c|c|}
\hline & Treatment Group (N=19) & Control Group (N=21) \\
\hline Mean Score Overall & 4.579 & 3.238 \\
\hline t-statistic & 2.042 & \\
\hline p-value & 0.024 & 2.905 \\
\hline t-statistic & 4.579 & \\
\hline p-value & 2.810 & 0.350 \\
\hline Mean Score General Questions & 0.004 & \\
\hline t-statistic & 1.474 & \\
\hline p-value & 3.452 & \\
\hline
\end{tabular}

With respect to the 10 general questions, the average score for the treatment group was significantly higher than the control group $(t=2.8, p<.01, \mu=4.6$ vs. $\mu=2.9)$. On the 5 current events questions, the average score for the treatment group was significantly higher than the control group $(\mathrm{t}=3.5 \mathrm{p}<.001, \mu=$

1.5 vs. $\mu=.4$ ). There were no statistically significant differences in scores for those who actually subscribed versus those who did not subscribe.

The subjects were all College of Business Majors at one small university; admittedly, the sample size was small and only one instructor's classes were utilized.

\section{DISCUSSION}

The data, although, exploratory, indicate that our business students are woefully uninformed on both general and current business issues. Many of these students are first generation college students from homes with little or no emphasis on reading. In the College of Business, almost all work at least part-time. Over $94 \%$ of the students in our university receive financial aid. Hence, many of them are economically disadvantaged. Requiring students to read is NOT enough; apparently, they are more likely to engage in reading (or, at least, have better recollection) when they are tested on these materials. This finding certainly reflects the literature on reinforcement [7], [9]. Moreover, "our" college students are as poorly informed as the general population described by Booth [1] and Clark \& Keller [2].

\section{REFERENCES}

[1] Booth, Michael. "Everything I Need To Know I Learned From My TV," The Denver Post, August 2006, 22, p. F1.

[2] Clark, S., \& Keller, L. "Young Americans Still Lack Basis Global Knowledge," National PTA. Retrieved from http://www.pta.org/archive_article details_1146587162031.html, October 6, 2006.

[3] Dessler, G. Human Resource Management, Upper Saddle River, NJ: Prentice-Hall, 2003.

[4] Garramone, G. \& Atkin, C. "Mass Communication and Political Socialization: Specifying the Effects." Public Opinion Quarterly, 1986, 50, 1, 76-86.

[5] Gomez-Mejia, L. \& Balkin, D. Compensation, Organizational Strategy, and Firm Performance. Cincinnatti: South-Western, 1992.

[6] Greider, Larry. "The Value of Reading," Vertical Thought, 2003. Retrieved on October 5, 2006 from http://www.ucgstp.org/lit/vt/vt03/reading.htm

[7] Harvey, C., \& Allard, J. Understanding and Managing Diversity. Upper Saddle River, NJ: Pearson/Prentice Hall, 2005. 
[8] Hopkins, Gary. “Why Teach Current Events?” Education World, 2005. Retrieved on October 6, 2006 from http://www.education-world.com/a_curr/curr084.shtml.

[9] Lawler, Edward. Strategic Pay. San Francisco: Jossey-Bass, 1990.

[10] "Magazines: Valuable Classroom Resource." Reading Today, Aug/Sept 2002: 18 EBSCO Publishing. 6 Oct. 2005.

[11] Mitchell, Thomas (2006). "No News Is Bad News For U.S. Democracy," Las Vegas Review-Journal, 2006. Retrieved October 7, 2006 from http://wf2la1.webfeat.org.

[12] Vaz, Valerie. "Ms. Fix-it." Essence 26, Aug. 1995: 40.

\section{APPENDIX 1}

\section{Current Events Business Quiz}

Please fill in the blanks below. If you do NOT know the answer, please do NOT guess.

1 What is the name of the current Chairman of the Federal Reserve Board of Governors?

$2 \quad$ Bill Gates is the chairman of the board of what company?

$3 \quad$ What is the name of the chairman of Berkshire Hathaway?

4 The stock market tends to rise when interest rates (increase or decrease - choose one).

5 Ken Lay was convicted in federal court of malfeasance in regard to his performance as CEO of what firm?

$6 \quad$ Which two world economies are the fastest growing this year? and

$7 \quad$ What famous management author coined the phrase "knowledge worker?"

$8 \quad$ What piece of federal legislation requires CEOs and CFOs to personally attest to the accuracy of a firm's financial statements?

9 What is the area in California that is the "hot place" for technological innovation?

10 In general, what causes housing markets to slow down?

11 What company is buying YOU TUBE?

12 What US Airline is attempting to buy DELTA?

13 Jeff Bezos, the president of , was on a recent cover of Business Week.

14 What kind of firm, called Gluttons at the Gate, buys either parts of OR even entire companies as investments for their clients?

15 What company hired private investigators to snoop around to find out who on their board of directors was leaking information?

Tell us about you:

Do you receive your own personal copy of Business Week magazine? YES NO

Gender: male female (circle one)

Class standing: freshman

( $0-29$ credit hours $)$

Sophomore (30-59 credit hours)

Junior (60-89 credit hours)

Senior (>89 credit hours) 